\title{
Does Corporate Governance Reduce Agency Costs in the Jordanian Industrial Companies?
}

\author{
HUTHAIFA AL - KARASNEH \\ Department of Financial and Administrative Sciences, \\ AL-Balqa Applied University/ Irbid University College, Jordan. \\ Email: huthaifa85@bau.edu.jo \\ Dr. ASHRAF BATAINEH \\ Department of Financial and Administrative Sciences, \\ AL-Balqa Applied University/ Irbid University College, Jordan.
}

\begin{abstract}
The study aims to measure the impact of corporate governance on reducing the agency costs in the Jordanian industrial public shareholding companies listed at Amman stock exchange, and to achieve this goal, the researchers studied the impact of corporate governance mechanism factors on reducing the agency costs, which can be represented in (Board size, institutional ownership, audit committee, debts ratio, dividends ratio, return on assets (ROA), and firm size). Agency costs were measured by using the following indicators: assets turnover ratio and operating expenses percentage. The study sample consisted of all industrial companies listed in Amman stock exchange, which have data available in this market during the period (2014-2016), and amount to 46 companies. The relationship between the corporate governance and agency costs was tested by relying on the generalized estimating equations (GEE) model, which align with the time period and study variables to test the study hypotheses. Study found a statistically significant positive relationship between the non-distribution of company profits and the agency costs represented in the variable (operating expenses ratio) in both cases of existence and non-existence of control variables in the study model. The results also showed that whenever control variables exist in the study model, there is a statistically significant positive relationship between ROA and the agency costs represented in the (asset turnover ratio) variable.
\end{abstract}

Keywords: Agency Costs, Amman Stock Exchange (ASE), Corporate Governance, Jordanian Industrial Companies, Generalized Estimating Equations (GEE) Model.

\section{Introduction}

Agency costs are cost of a firm due to self-serving behaviors on part of the managers who focus on empirebuilding objectives, excessive perquisite consumptions, non-optimal investments decision-making, acts of accounting misconduct, or corporate frauds (Jensen, 2000). The adverse implications of these actions are then felt in the form of destruction of shareholder's wealth and wider impacts on other corporate stakeholders, such as debt providers, employees, and society in general. The recognition of the consequences flowing from the agency problems occurrence have led to place emphasis on the importance of competitive markets for managing labor and corporate control, where monitoring the mechanisms designed to limit the degree of agency divergence, the role of institutional shareholders as substitute agency devices, and the development and enforcement of corporate governance practice codes to enhance management oversight and create the desirable incentive structures within firms (Jensen, 2000). According to Jensen (2000) corporate governance mechanisms are found to lowers the agency costs level and that internal governance and external shareholding influences are substitute agency-mitigating mechanisms. 
Corporate governance has been recognized as one of the needed significant tools to deal with the agency problems, in order to manage any organization including corporation, and it has been defined in several ways. This study essentially will use the definition of corporate governance by the organization for economic cooperation \& development (OECD), which defines good corporate governance as the rules and practices that govern the relationship between the managers and shareholders of corporations, as well as stakeholders, such as employees and creditors, who contribute to the growth and financial stability by underpinning the market confidence, financial market integrity, and economic efficiency (OECD, 2004).

However, recently we have seen much more evidence of the opposite, where major world corporate crises have shown the weakness of existing governance mechanisms resulting in accounting scandals and corporate collapses. In response, regulation bodies have regulated new corporate governance principles to control any future conflict of interest. The biggest event are the recent series of corporate collapses in 2001/2 that led the US Congress to formulate and issue the Sarbanes Oxley Act in 2002, and highlighted the importance of corporate governance to ensure the alignment of interest between managers and shareholders (Clarke, 2004).

Agency costs problem is increasing in many of the Jordanian industrial public shareholding companies, especially with the fact that Jordan considers one of the non-developing countries, where markets in it are characterized by a low level of development and competition, and a low liquidity that makes it important to develop various mechanisms, which can be possible through it to address and solve this problem and its negative effects, as it become a burden on the owners and threaten the companies to collapse through the decline of market value. Therefore, it's necessary to search for the way that can be used to reduce the agency costs by looking for the most important mechanisms that have impact on it and lead to reduce it. The important question of the study is: What is the contribution level of some internal corporate governance mechanisms on reducing the agency costs in the Jordanian industrial public shareholding companies listed at Amman stock exchange ASE?

Ever since the beginning of the 1990s, Jordan has practice a liberalize financial system, through adopting a collection of well-planned restructured projects to enhance the effectiveness of the economy, raise its competitiveness level, and fit it in with the international economy. Nevertheless, ASE has been under the influence of the international finance crisis that happened in 2008, and its stock prices have been dropping ever since, but the turn down were at low rates compare with the other Arabic and international stock exchanges (Zurigat \& Gharaibeh, 2011).

Therefore, this study derives its importance from the role played by the Jordanian industrial public shareholding companies in developing and strengthening of Jordan's economy (Rababah \& Bataineh, 2016), where the corporate governance rules and foundations at the present time become one of the important major aspects to ensure the progress and continuity of these companies, which form in itself an important element to achieve the economic reform, and consider as a proof on policies and rules existence to protect investors, and as a mean to promote the confidence in economy. In addition, the study outputs in general are important for researchers, and it's also important for the industrial companies, in specific by assisting them to attract investments and increase the competitiveness between these companies and the companies similar to it, internally and externally. Therefore, the pledge to implement the corporate governance internal mechanisms, which can be represented in (Board size, institutional or corporate ownership, audit committee, debts ratio, dividends ratio, return on assets ROA, and firm size) will lead to reduce the agency cost problems, and achieve the synergy between the interests of managers and owners, which in turn leads to protect these companies, and help it to continue and succeed.

From here, this study aim to identify the contribution level of some institutional and corporate governance mechanisms to reduce the agency costs in the Jordanian industrial companies listed at (ASE) between (2014-2016), represented in (Board size, institutional ownership, audit committee, debt ratio, dividend ratio, ROA, and firm size). 


\section{Conceptual Framework}

\section{Corporate Governance}

Corporate governance is a set of relationships between the shareholders of the company, its board of directors, and other shareholders. The corporate governance focus on monitoring companies, through effective corporate governance mechanisms, by forcing managers to follow interests of the principles (OECD, 2004).

The following alternative empirical variables were used to signify the corporate governance mechanisms:

\section{Board Size}

The small boards are related to better firm performance. The process of comparing the small boards with the large boards is associated with the increased problem of communication and coordination, and decreased the ability to control management. Whenever board size increase, the conflict of interests rise and it would be difficult for CEO to control the larger boards (Yermack 1996). According to Pearce and Zahra (1991) boards that are small in size are more effective and organizationally functional (Gul et al., 2012). In a study, Singh and Davidson (2003) found that firms with higher utilization ratio are associated with minimum agency costs, but on the opposite side in a sample of UK listed firms for the period (19992003) Florackis and Ozkan (2004) used assets turnover ratio as a alternative for agency costs and discovered that board size and turnover ratio are negatively correlated, indicating greater agency costs for larger boards.

\section{Institutional Ownership}

Institutional ownership reflects the amount of company stocks that institutions or bodies own, where many studies showed that institutional ownership has positive role in the control of the company. (Osagie et al., 2005) reached the conclusion that companies with high institutional ownership ratio, their agency costs would be reduce because the institutional owners have the ability to control management behavior, in addition to their ability to obtain a lot of information that may not be available to other investors, and their existence also give the company immunity, due to the low liquidity of their stocks and the lack of its circulation in the financial market .

\section{Audit Committee}

The audit committee considers as one of governance tools that promote and increase the volume of disclosed financial information, leading to the reliability and transparency, where this committee prepare the financial report and oversees the internal audit process in the companies. It also supports the external audit through its boards to strengthen its independence, by committing to the governance principles of corporate, and it also differentiate by its separation from the council and the membership limited to members of the non-executive management board, who have several characteristics such as audit, and experience and independence in the field of accounting. Its responsibilities also determine by reviewing the financial reports preparation process, auditing the internal and external processes, and checking the corporate commitment to the implementation of corporate governance rules and principles, set forth and agreed to in the board of management (Brooch, \& Al-Hashemi, 2012).

\section{Debt Ratio}

Debt ratios consider the most effective way to avoid misuse of the agency costs, where in order to reduce the cost of exaggeration in investment, companies must increase the level of debts in its financial structures, which make the available liquidity volume under the management disposal limited, because the 
debt ratios place strong restrictions on the management, through company exposure to the risks of bankruptcy, in the case of failure to pay the debt, and therefore reduce the ability of managers to invest in projects that aren't economically viable, thus reduce the agency costs of the company (Jensen,1986).

\section{Dividend Ratio}

The dividends and profits distribution contribute by hosting the agency disputes between the managers and shareholders, and as a result dividend distribution work on reducing the agency costs, through returning shareholders' funds to them and prevent managers from using it for their own interests (Belden et al., 2005).

Dividends distribution and its relation with the agency costs can play an important role in the topic of company control and command, and when the dividends get distributed the managers at the company could deprive from exploiting the financial surpluses to achieve their special interests, which contributes to the increase control of lenders and the financial market of the company (Easterbrook, 1984).

\section{Return on Assets}

ROA ratios are measured by dividing the company's net profit on its total assets, where this percentage considers one of the most important indicators in the profitability assessment at the company. It's also express the range of returns power earned by the invested assets, and it also gives a clear perspective to optimally invest in the resources obtained from the various sources of funding (Matter, 2003, p 46).

\section{Firm Size}

Empirical researches have documented negative relationship between the firm size and its relative value. This negative correlation between size and value has been referred to as the size discount and has been observed because large firms are relatively less valuable than smaller firms. Shareholders have been observed to not be able to minimize agency costs in large firms, which mainly return to the weakness of internal and external corporate governance mechanisms as firms grow larger (Jensen, 1986). Large firms are thus expected to have higher agency costs than the small firms.

\section{Agency Cost}

We have used the assets turnover ratio and operation expenses to measure agency costs, as shown below:

\section{Asset Turnover Ratio}

It's the ratio that measures the effectiveness level of investment decisions taken by the management of the company and its ability to utilize the assets optimally; where this ratio will be measured by dividing the total sales on the total assets, has been used in the following studies (Ang et al., 2000), (Florackis \& Ozkan, 2004), (McKnight \& Weir, 2009).

\section{Operation Expenses Ratio}

Sign and Davidson (2003), used the selling ratio, by comparing administrative and general expenses to sales (expenses ratio), where expenses include salaries, commissions charged by agents to facilitate transactions, travel expenses for executives, advertising and marketing costs, and rents and other utilities. Therefore, the expenses ratio should reflect to a significant extent the managerial discretion to spend company resources. 


\section{Literature Review}

The study of (shagoor, 2017) aims to address the elements that impact agency costs in the commercial banks listed at the ASE. Researchers studied the impact of several factors on reducing the agency costs, such as board size, independent members of the board ratio, audit committee meetings ratio, corporate ownership, family ownership, ownership concentration, debt financing, bank market shares, and bank size, where the agency costs are measured by using three indicators, which are assets turnover index, operating expenses index, and free cash flow index, and the study sample consist of all commercial banks listed on the ASE, and have the necessary data during the study period (2013-2015). The study results indicate that agency costs will increase with the increase in board size, but in regard to the independent member ratio, audit committee meetings ratio, corporate ownership, family ownership, debt financing, and the bank market share, it decrease with the increase in ownership concentration, and in regard to assets turnover index, the agency costs increase with the board size.

The goal of (Garanina, \& Kaikova, 2016) paper is to examine whether some corporate governance mechanisms, such as board size, board composition, leverage, and firm size lean to alleviate the agency costs occurrence in the USA, Russia, and Norway. The researchers analyzed the sample of 243 Americans, 196 Russians, and 175 Norwegians joint stock companies for the period of (2004-2012). The regression analysis was implemented to test the models, and it revealed that larger boards increase the agency costs (measured by assets utilization ratio and assets liquidity ratio) in all sample companies. The proportion of female members has a very slight positive effect in US companies, a negative influence on agency costs in the Norwegian sample, and non-significant effect in the Russian market. The researchers also find that big Russian and US companies in the samples of this paper have lower agency costs.

But the (Zurigat, et al, 2016) study aimed to measure the impact of several internal governance mechanisms on reducing agency costs for a number of industrial companies listed at ASE for the (2000-2013). These mechanisms are (Debt financing, board size, corporate ownership, and management rewards). The study used time series data (Panel) for 58 companies, and arrives to the existence of statistically significant inverse relationship between the level of debt financing and the agency costs, a direct correlation between the management rewards and the agency costs, and the non-existence of statistically significant relationship between the corporate ownership and the agency costs.

The study of (Hamdan et al, 2016) aimed to highlight the ownership structures of companies listed on the Bahrain stock exchange, and its role in reducing the agency costs, by dividing the ownership structures into the following four basic components: Ownership concentration, board ownership, corporate ownership, and foreign ownership. The study depend on the longitudinal data of (31) companies, for a time series of (20022014), and used the firm fixed-effect model. The study found that ownership structure components play a negative role in the agency costs of companies listed on the Bahrain stock exchange, except for board ownership which played a non-effective positive role in reducing the agency costs.

Where the study of (Mansor et al., 2013 aimed to support the claim that corporate governance mechanisms are able to overcome the profit management activities, from the viewpoints of both family and non-family businesses. A sample of 264 Malaysian companies was selected on the basis of an applied sample study. The study results showed that number of held board meetings in the family business, management independency, audit committee size, and the internal audit career in the non-family businesses are all governance mechanisms that were created to reduce the earnings management activities.

The study of (Yegon et al., 2014) aimed to measure corporate governance impact analysis on the agency costs for a sample consist of nine companies, from the service sector at Nairobi stock exchange in Kenya, during the period (2008-2012), where the agency costs were measured by the assets turnover, while the corporate governance were measured by the institutional ownership, management ownership, external ownership, board size, and board independence. The study results showed that agency costs decrease by the 
increase in the institutional and management ownerships, and showed that agency costs drop every time board size decrease. The study results also showed a positive relationship between board independence and assets turnover.

While the study of (Siddqsui et al., 2013) aimed to measure the analyses of many institutional governance mechanisms impact on the agency costs, for the period (2003-2010) in 120 companies at Karachi stock exchange, where the agency costs were measured by using two indicators represented in liquidity ratio and assets turnover. The researcher used a number of independent variables, such as number of board meetings and board size. The study results showed a positive relationship between the board size and liquidity ratio, while the results showed a negative relationship between number of board meetings and the liquidity ratio.

However, the paper of Ramadan (2010) aimed to shed lights on the role of corporate governance devices in justifying the agency problem for the Jordanian industrial corporations. This was done through investigating the effect of internal corporate governance devices, such as ownership structure, board of directors, and capital structure. Their effect on the assets turnover as an opposite alternative for the agency costs has been investigated depending on the cross-sectional regression analysis. The findings of this paper revealed that ownership structures, mainly ownership concentration and the characteristics of board directors, such as board size, board independency, and the separation between the board chairman and the executive director represent important corporate governance devices for the Jordanian corporations. The results also revealed that impact of these devices varies along with company's growth opportunities.

While the study of Wang Junwei, Lu and He (2010), was based on the panel data for the period (20062009), and they used four alternatives of agency costs: assets turnover ratio, sales and management expenses ratio, free cash flows, and assets liquidity ratio to examine the level of agency costs implemented in China's A-share listed companies, and evaluate governance and ownership attributes that are assumed as justifying agency costs and implemented fixed effects regression analysis methods. The results indicate a significant positive relationship between the free cash flows and board characteristics. The relations between the other three variables of agency costs and board characteristics are not significant. Board size, independent directors' ratio, and unity of chairman and general manager are indistinctively correlated with the assets turnover ratio, sales and management expenses ratio, and free cash flows. The results also indicate non-significant relationship between the four dependent variables used as an alternative for the extent of agency costs and managerial ownership.

According to the previous empirical reviews and studies, we can conclude that many researchers have examined the relationship between variety of corporate governance practices and agency costs. However, their findings are diverse where some examine only the impact of one governance mechanism on agency cost or performance, and in addition most of the studies were done in developed markets or emerging markets, thus the strength of their results weren't adequately tested in non-developed countries like Kenya. Therefore, this study hunt to fill this literature gap since none of the previous studies did cover the relationship between director ownership, board composition, board size, CEOs unity, ownership concentration, and agency costs; specifically with the manufacturing and allied firms listed at NSE.

\section{Research Hypotheses}

The following hypotheses have been tested in this study:

Main hypothesis $\mathbf{H}_{01}$ : Corporate governance doesn't have a positive effect on agency costs in the Jordanian industrial companies.

This main hypothesis was divided into the following seven sub-hypotheses:

Sub-hypothesis $\mathbf{H}_{01-1}$ : Board size doesn't have a positive effect on agency costs in the Jordanian industrial companies. 
Sub-hypothesis $\mathbf{H}_{01-2}$ : Institutional ownership doesn't have a positive effect on agency costs in the Jordanian industrial companies.

Sub-hypothesis $\mathbf{H}_{01-3}$ : Audit committee activities don't have a positive effect on agency costs in the Jordanian industrial companies.

Sub-hypothesis $\mathbf{H}_{01-4}$ : Debts ratio doesn't have a positive effect on agency costs in the Jordanian industrial companies.

Sub-hypothesis $\mathbf{H}_{01-5}$ : Dividends ratio doesn't have a positive effect on agency costs in the Jordanian industrial companies.

Sub-hypothesis $\mathbf{H}_{01-6}$ : Return on assets (ROA) doesn't have a positive effect on agency costs in the Jordanian industrial companies.

Sub-hypothesis $\mathbf{H}_{01-7}$ : Firm size doesn't have a positive effect on agency costs in the Jordanian industrial companies.

\section{Data \& Methodology}

\section{Sample characteristics and data collection}

We have selected 46 industrial companies on the basis of market capitalization listed on the Amman Stock Exchange "ASE" (www.ASE, 2018), (Bataineh \& Rababah, 2016) for the period (2014-2016). Secondary data were collected from companies' financial statements, Amman Stock Exchange, and company's websites.

To test the relationship between corporate governance and agency costs, the GEE model was used which align with the study period and variables, and was represented within the following equation:

$$
\mathrm{AGC}=\beta 0+\beta 1 \mathrm{BS}+\beta 2 \mathrm{IO}+\beta 3 \mathrm{AC}+\beta 4 \mathrm{DR}+\beta 5 \mathrm{D}+\beta 6 \mathrm{ROA}+\beta 7 \mathrm{FS}+e
$$

\begin{tabular}{|l|l|}
\hline Measurement methods & \multicolumn{1}{c|}{ Institutional indicators } \\
\hline Number of management board members & BS (Board size) \\
\hline Institution ownership share ratios & IO (Institutional ownership) \\
\hline Yes (committee existence), No (non-existence of committee) & AC (Audit committee) \\
\hline Total debts / Total assets & DR (Debt Ratio ) \\
\hline Distributed dividends/ Net profits & D (Dividend Ratio ) \\
\hline Profits before taxes/ Total assets & ROA (Return on Assets) \\
\hline Total assets & FS (Firm Size) \\
\hline
\end{tabular}

\section{Data Analysis}

Descriptive statistics were used to describe the sample by using median and inter-quartile range for continuous variables, and frequencies and percentages for categorical variables.GEE were used to create regression models for the dependent variables, and is suitable for analyzing the longitudinal data collected for the purpose of this study, over three years period where GEE is more powerful than the general linear model, especially for small sample sizes (Burton, Gurrin, \& Sly, 1998; Minke, 1997; Vittinghoff, Glidden, Shiboski, \& McCulloch, 2012). Since both of the dependent variables (assets turnover and operational expenses ratio) follow a normal distribution, we used linear models in the GEE for both variables. Specifically, four multivariate models were created; two for each dependent variable with and without counting the control variables. Robust estimator with exchangeable correlation matrix was also used, due to the non-independency among repeated measures within the subjects. In addition, other correlation structures were investigated and yielded similar results and SPSS (version 25; IBM Corp, Armonk, NY) (IBM Corp, 2017) was used for data analysis and p-values <.05 was considered as significant. 


\section{Results of data analysis}

Table (1): Characteristics of the sample; median (interquartile range [IQR]) or frequency

\begin{tabular}{|l|c|c|c|}
\hline \multirow{2}{*}{ Variable } & \multicolumn{3}{|c|}{ Year } \\
\cline { 2 - 4 } & $\mathbf{2 0 1 4}$ & $\mathbf{2 0 1 5}$ & $\mathbf{2 0 1 6}$ \\
\hline Independent & $8(6.3,9)$ & $7(6,9)$ & $7(6,9)$ \\
\hline Board size of the committee & $38(79 \%)$ & $38(79 \%)$ & $38(79 \%)$ \\
\hline Audit committee, yes & $33(18,46)$ & $30(16,46)$ & $30(18,44)$ \\
\hline Debts ratio & $33(9,54)$ & $33(10,59)$ & $37(11,60)$ \\
\hline Institutional ownership & $21(45.7 \%)$ & $19(41.3 \%)$ & $20(43.5 \%)$ \\
\hline Profits/ dividends, yes & $3(-0.41,8)$ & $3(-4,6)$ & $3(-4,7)$ \\
\hline Control & $18(10.4,56.7)$ & $18.2(10.4,61.2)$ & $18.3(11.5,65.6)$ \\
\hline Return on assets & \multicolumn{3}{|c|}{} \\
\hline Firm size-total assets in million JD & $0.7(0.44,1)$ & $0.7(0.40,91)$ & $0.53(0.31,0.78)$ \\
\hline Dependent & $0.81(0.69,0.87)$ & $0.85(0.65,0.88)$ & $0.82(0.62,0.92)$ \\
\hline Assets turnover
\end{tabular}

Characteristics of the sample, for the three years periods are presented in table (1), where the values for the characteristics stayed almost the same across the three years except for institutional ownership, which increased in 2016. The mean assets turnover ranged between (0.53-0.7), while operational expenses ratio were between (0.81-0.85).

Table (2): Multivariate predictors for operational expenses and assets turnover without control variables,

\begin{tabular}{|c|c|c|c|c|}
\hline \multirow{3}{*}{ Variables } & \multicolumn{4}{|c|}{ Dependent variables } \\
\hline & \multicolumn{2}{|c|}{ Operational Expenses } & \multicolumn{2}{|c|}{ Assets Turnover } \\
\hline & $\beta$ & P-value & $\beta$ & P-value \\
\hline Independent Variables & 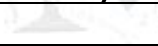 & & & 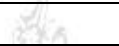 \\
\hline Board size & -.006 & .59 & -.001 & .96 \\
\hline Debts ratio & .001 & .57 & .009 & .12 \\
\hline Institutional ownership & .000 & .86 & -.002 & .24 \\
\hline Dividends, No & .153 & $.003 *$ & -.026 & .72 \\
\hline Audit committee, No & -.120 & .22 & -.140 & .28 \\
\hline
\end{tabular}

$* \mathrm{P}<.05 \quad * * \mathrm{P}<.01$

Results from the GEE models, without accounting for the control variables are displayed in table (2). Firms that didn't offer profits or dividends in one year had higher operational expenses compared with firms that offered dividends $(\beta=.153, \mathrm{p}=.003)$. There were no significant predictors of assets turnover.

Table (3): Multivariate predictors for operational expenses and assets turnover with control variables, for the period (2014-2016)

\begin{tabular}{|l|c|c|c|c|}
\hline \multirow{2}{*}{ Variables } & \multicolumn{4}{|c|}{ Dependent Variables } \\
\cline { 2 - 5 } & Operational expenses & \multicolumn{2}{c|}{ Assets turnover } \\
\cline { 2 - 5 } & $\boldsymbol{\beta}$ & $\boldsymbol{P}$-value & $\boldsymbol{\beta}$ & $\boldsymbol{\beta}$-value \\
\hline Independent variables & & & & .92 \\
\hline Board size & -.005 & .64 & .003 & .05 \\
\hline Debts ratio & .002 & .26 & .012 & .11 \\
\hline Institutional ownership & -.001 & .63 & -.003 & .89 \\
\hline Dividends/ Profits & .172 & $.003^{* *}$ & .01 & \\
\hline
\end{tabular}




\begin{tabular}{|l|c|c|c|c|}
\hline Audit committee, No & -.130 & .17 & -.172 & .23 \\
\hline Control Variables & & & & \\
\hline Return on assets & .003 & .15 & .003 & $.001^{* *}$ \\
\hline Firm size & .000 & .92 & .000 & .88 \\
\hline
\end{tabular}

$* \mathrm{P}<.05 * * \mathrm{P}<.01$

Table (3) showed the results from the GEE models with accounting of the control variables. Dividends stayed the only predictor of operational expenses after controlling the return on assets and firm size $(\beta=$ $.172, \mathrm{p}=.003)$. However, the control variable return on assets was the only predictor of assets turnover $(\beta=$ $.003, \mathrm{p}=.001)$.

\section{Conclusions \& Recommendations}

This study aims to examine the impact of corporate governance on agency costs in the Jordanian industrial companies listed in ASE, by using both descriptive and quantitative ratio analysis. In order to achieve this objective, the study addressed the theoretical aspects of corporate governance by reviewing the concepts, objectives, methods, and effects, and also by examining some of the studies in world countries in general, and non-developed countries in particular.

\section{Conclusions}

The study arrived to the following results:

1. There is a statistically significant positive relationship between the non-distribution of profits or dividends at the company and agency costs represented in the variable (operational costs ratio), in both cases of existence and non-existent of control variables at the study model.

2. There is a statistically significant positive relationship between ROA and agency costs, represented in the variable (assets turnover rate) in case of control variables existence at the study model.

3. Data collection results showed more commitment by the Jordanian companies to implement the corporate governance rules compare with previous years and studies.

4. Dividends distribution ratio considers one of the effective internal mechanisms in reducing the agency costs in the Jordanian industrial companies.

5. The study shows an reverse relationship between the debt financing level and agency costs, where agency costs in the Jordanian industrial corporations increase, in case of large board size, while it decrease in the small board size.

\section{Recommendations}

An attempt was made to provide set of various practical recommendations, which may contribute to the enhancement of corporate governance mechanisms, some of those are:

1. The study recommends the need to alleviate the problem of asymmetric information at Amman stock exchange, by increasing the disclosure level at these companies, in order to raise the transparency level, which increases the confidence of investors in the company, and as result reduce the high agency costs problem.

2. The study recommends holding specialize courses and seminars about the development of cognitive, philosophical, and procedural framework for the corporate governance concept, which contribute to strengthen the effective implementation of institutional governance elements, through the establishment of regulatory, organizational, judicial, and legislative institutions, which are responsible for the tasks of executing and following up implementation mechanisms of corporate governance laws in the companies, by using a system to measure the performance, and for evaluation and follow up.

3. The study recommends the need to conduct further prospective studies, which expand on the corporate 
governance topic and its impact on the agency costs, where the study population won't only be limited to the industrial sector in Jordan, but also include other sectors, such as commercial sector, universities, hospitals, insurance, telecommunications, and other sectors, in order to shed light on the variation range of implementing institutional governance internal methods at these sectors.

\section{References}

Ang, J., Cole, R., \& Lin, J. (2000). Agency costs and ownership structure. the Journal of Finance, 55(1), 81-106.

Bataineh, A., \& Rababah, A. (2016). Comprehensive Income and Net Income, Which is more powerful in predicting Future Performance. International Journal of Academic Research in Accounting, Finance and Management Sciences, 6(2), pp 114-120.

Belden, S., Fister,T., and Knapp, B. 2005. "Dividends and Directors: Do Outsiders Reduce Agency Costs?". Business and Society Review, 110(2): 171-180.

Brooch, Z, \& Al-Hashemi, J. (2012), The Role ofgovernance mechanisms in reducing Financial and administrative corruption. A working paper presented to the National Forum on: Corporate Governance as a Mechanism of Reduction From Financial and Administrative Corruption, Algeria: University of Mohamed Khaydar.

Burton, P., Gurrin, L., \& Sly, P. (1998). Extending the simple linear regression model to account for correlated responses: an introduction to generalized estimating equations and multi-level mixed modelling. Stat Med, 17(11), 1261-1291.

Clarke, T., (2004), 'Cycles of crisis and regulation: the enduring agency and stewardship problems of corporate governance', Corporate Governance, 12, 153-161.

Easterbrook, F. 1984. "Two Agency-Cost Explanations of Dividends". American Economic Review, 74(4): $650-659$.

Florackis, C. and Ozkan A. (2004). Agency Costs and Corporate Governance Mechanisms: Evidence for UK Firms, Working Paper, University of York, UK.

Garanina, T., \& Kaikova, E. (2016), "Corporate governance mechanisms and agency costs: cross-country analysis", Corporate Governance, 16(2), 347-360.

Gul, S., Sajid, M., Razzaq, N., and Afzal, F. (2012). Agency Cost, Corporate Governance and Ownership Structure", International Journal of Business and Social Sciences, vol. 3(9).

Hamdan, A, Anasoh, M and Al-Saree, A (2016), "Ownership structure in the companies listed in Bahrain stock exchange and its role in reducing the agency costs", the Islamic University journal for the economic and management studies, 24(4), 82-98.

IBM Corp. (2017). IBM SPSS Statistics for Macintosh, Version 25.0. Armonk, NY: IBM Corp.

Jensen, M. C. (2003). A theory of the firm: governance, residual claims, and organizational forms. Harvard University Press.

Jensen, M. C. (1986). Agency costs of free cash flow, corporate finance, and takeovers. The American economic review, 76(2), 323-329.

Li, H., \& Cui, L. (2003). Empirical study of capital structure on agency costs in Chinese listed firms. Nature and science, $1(1), 12-20$.

Mansor, N., Che-Ahmad, A., Ahmad-Zaluki, N. A., \& Osman, A. H. (2013),"Corporate governance and earnings management: A study on the Malaysian family and non-family owned PLCs", Procedia Economics and Finance, 7, 221-229.

Mcknight, P. J., \& Weir, C. (2009). Agency costs, corporate governance mechanisms and ownership structure in large UK publicly quoted companies: A panel data analysis. The Quarterly Review of Economics and Finance, 49(2), 139- 158.

Minke, A. (1997). Conducting Repeated Measures Analyses: Experimental Design Considerations. Paper presented at the annual meeting of the Southwest Educational Research Association, Austin, TX.

OECD (2004), The OECD Principles of Corporate Governance, viewed 26 November 2008 $<$ www.oecd.org/daf/corporate/principles/>. 
Osagie, J., Osho, G.S., and Sutton, C. 2005. The Impacts of Institutional Stock Ownership on Stock Returns and Performance: A Financial Market Perspective, Journal of Business and Economic Research, 3 (3): 65-70.

Pearce, J. A., and Zahra, S. A., (1991). The relative power of CEOs and boards of directors: associations with corporate performance, Strategic Management Journal, .12: 135-53.

Rababah, A., \& Bataineh, A. (2016). Factors Influencing Balanced Scorecard Implementation. Research Journal of Finance and Accounting, 7(2), 204-212.

Ramadan, (2010). Managerial Agency Cost and Corporate Governance Devices Evidence from Jordan. Egyptian Journal of Commercial Studies - Egypt, Vol. 34, p. 3, 155 - 179. Retrieved from http://search.mandumah.com.

Shagoor, A (2017), " The influencing factors of agency costs: an empirical study of commercial banks listed at Amman stock exchange", Arabic journal for sciences and researches publishing, national center for researches at Gaza, (3) 2, 27-42.

Siddqisui, M., Razzaq, N., Malik, F., and Gul, S.( 2013). Internal Corporate Governance Mechanisms and Agency Cost: Evidence from Large KSE Listed Firms, European Journal of Business and Management, 5 (23)

Singh, M., and Davidson, W.N. 2003. Agency costs, ownership structure and corporate governance mechanisms, Journal of Banking and Finance, 27: 793-816.

Vittinghoff, E., Glidden, D. V., Shiboski, S. C., \& McCulloch, C. E. (2012). Regression methods in biostatistics: linear, logistic, survival, and repeated measures models (Second edition. ed.). New York: Springer.

Wang Junwei, Lu \& He (2010). Study on the Relationship between Agency Cost and Governance Mechanisms: Evidence from China ${ }^{e c}$ A-share listed companies.

www.ase.com.jo/ (ASE) Amman Stock Exchange 2017

Yermack, D. 1996. Higher Market Valuation of Companies with Small Boards of Directors, Journal of Financial Economics, 40: 185-211.

Yegon, C., Sang, J., Kirui, J. (2014). The Impact of Corporate Governance on Agency Cost: Empirical Analysis of Quoted Services Firms in Kenya, Research Journal of Finance and Accounting, 5 (12).

Zurigat, Z., \& Gharaibeh, M. (2011). Financial Liberalization and Investment Sensitivity to the Cash Flow. European Journal of Economics, Finance and Administrative Sciences,42(76-89).

Zurigat, Z. Al-Gharaibeh, M \& Al-Hadad, L (2016), "Agency costs and the corporate governance: manual for the Jordanian industrial companies listed at Amman stock exchange", Jordanian journal of business management, Jordan, (12) 2, 307-329. 